\title{
Influence of the Board of Management Financial Practices on Students' Academic Performance in Public Secondary Schools in Nyamira County Kenya
}

\author{
Ondara Kennedy Kokemwa* Momanyi Marcella Anyona Ntabo \\ Catholic University of Eastern Africa P.O. BOX \\ 62157 - 00200, Nairobi - Kenya \\ *Corresponding author email: kokemwa18@gmail.com
}

\begin{abstract}
The Board of Management plays an important role in school management which encompasses policy formulation and resource allocation. This study therefore sought to investigate the influence of the Board of Management financial practices on students' academic performance in public secondary schools in Nyamira County, Kenya. A convergent parallel mixed-method research design was used. The study targeted students, teachers, departmental heads and Board of Management Members making a total study population of 19,609. Both probability and nonprobability sampling methods were used to select a sample size of 396 participants. Data was collected using questionnaires, interview guide observation tool and school examination performance analysis document. Statistical package for social sciences aided the quantitative analysis, while qualitative data used thematic analysis technique. Reliability testing was done using Cronbach's Alpha. Descriptive and inferential statistics were used to present the analyzed data. Analysis of variance (ANOVA) was used to test significance between means. The study found out that there was a statistical significant association between board of management financial practices and student academic performance. The study also found out that Board of management did not utilize the school finances well and therefore students' academic performance was affected. The study recommended that Board of Management, in collaboration with the government, should ensure appointment of board members with some basic financial management literacy.
\end{abstract}

Keywords: Board of Management, Students' Academic Performance, Financial Management.

DOI: $10.7176 / \mathrm{JEP} / 11-23-02$

Publication date:August $31^{\text {st }} 2020$

\section{Introduction}

Financial accounting and reporting is at the core of any schools' financial and academic success. An error in how school finances are handled could prove costly towards school performance (Shkurina, 2018). In the recent past, most countries have allocated a lot of resources to the education sector in their budget to enhance their manpower requirements for economic development (Roser \& Ortiz-Ospina, 2016). This calls for good governance in the management of the resources in the public learning institutions. Good governance in education systems promotes quality education, which supports a country's human resource development necessary for economic growth (Lewis \& Pettersson, 2009).

In a school set up, governance is entrusted to the School's Board of Management (BOM) (Said, 2016). It is the role of the board of directors to carry out internal monitoring to protect the interest of school stakeholders (Molano-León, 2011). Generally, the board's functions include the control, service, and resource dependence roles. According to Kwesi, Arko \& Maison (2018), most of the school governing boards lack adequate skills in the drafting of budgets, writing financial and policy statements, control of finance and petty cash, initiative and innovation as well as accountability.

In the United States of America, the Schools' Boards of Management have considerable influence over education decisions, such as the management of resources. A school board in the USA has the following responsibilities: Develop policies and regulations, control operations of schools, control school finances, equipment purchase and maintenance, and resource management. The school boards initiate educational policies at the local level and have a responsibility towards excellence in education (World Bank Group 2014).

In the majority of the Sub-Saharan African nations, the obligation of directing the administration of schools is dependent on School Board of Management councils (World Bank Group, 2014).However, it has been noted that some of the Board members are not well versed in financial resource management because they lack the required financial education and training (King'oina, Ngaruiya \& Mobegi, 2017).

In South Africa, school management bodies experience many challenges. These include: problems in drafting school budgets, writing financial statement, financial policy, as well as control of finance (Madikela, 2006). Madikela recommended training of the BOM members as the best remedy for such problems. Newly elected BOM members may further experience difficulties in running the school. New BOM members' competency may be affected by inadequate induction on their responsibilities and roles, low education, inadequate exposure, and 
inexperience (Kalungu, 2015).

In Zimbabwe, there are difficulties in the administration of school funds by school heads. Tichaona (2014) observes that most heads of schools came up short on the satisfactory bookkeeping proficiency required for compelling administration of school funds and that there was practically no supervision at all from the Ministry of Primary and Secondary Education money office workforce on budgetary administration and other related issues.

Mismanagement and misappropriation of school funds directly affect the quality of education (Nyakundi, Okiaga, Ojera, Nyabwanga \& Nyamwamu, 2008). Inefficiencies in financial management of most public secondary schools contribute to the decline in quality of education. Further, there has been reluctance or failure of school heads to submit their books of account for annual audit. There was also a delay in submitting monthly trial balances to the audit office (Transparency International, 2011).

In Kenya, public secondary schools have experienced various problems from time to time, occasioned by governance issues. In education, generally, ineffective governance affects educational standards negatively, leading to substandard delivery services and poor student performance. School financial controllers are the school principals and the accounting officers, whereas the Board of Management members are in charge of the policymaking (Langat, 2008). Asiago as cited by Kalungu (2015) observes that both of them lack financial qualifications to enable them to execute their duties effectively.

Additionally, the BOM members also lack the necessary technical skills to understand and interpret financial reports in making decisions (Mobegi, Ondigi \& Simatwa, 2012). Ironically, having a minimum qualification of secondary education certificate, being a person of integrity, and committed to serve the community voluntarily qualifies an individual as a BOM member (Ministry of Education Science and Technology, 2014). In extension, the regulation provides that the chairperson of the BOM must have at least a degree and be a person of integrity without any business of interest with the school. Kalungu (2015) indicates that the level of education of Board of Management members, their professional status, gender, and the nature of the job done has a positive influence on the effectiveness of BOMs financial management.

The board of management is significantly involved in financial planning and management in schools. As such, control of expenditure is one of their key mandates. Therefore, decisions and policies that are implemented are likely to influence school practices including academic performance. Schools in Nyamira County have been seen to post poor examination results during national examinations. Few studies (Kalungu, 2015; Langat, 2008;Mobegi, Ondigi \& Simatwa, 2012) have linked the role that BOM plays in students' academic performance and how their financial practices play a role in academic performance of students. Thus, this study sought to investigate the influence of the board of management financial practices on students' academic performance in public secondary schools in Nyamira County Kenya.

\section{Literature Review}

According to Johnsons and Scholes (2012), it is the role of the board of directors to carry out internal monitoring to protect the interest of school stakeholders. Generally, the board's functions include the control, service, and resource dependence roles. According to the agency theory perspective, the board acts as a primary internal mechanism for controlling the behavior and interest of both the managers and the stakeholders (Jansen, 2013). Scholars argue that the size and composition of the board has an influence on the effectiveness of monitoring school activities. Furthermore, the existing conflicting views on the board composition are associated with the degree of agency problems (Borokovich, 2006 as cited in Jasen, 2013).

South Africa School Act of 1996 [revised in 2011] supports the creation of the school governing bodies. The Act provides that the school board needs to consist of principal, parents' representatives, teachers, non-teaching staff, and the students. As stipulated in section 21 of that Act, the board is mandated to maintain school property, purchase textbooks, educational materials, and equipment and pay for services rendered to the school. According to a study conducted by Nombasa (2014), most of the school governing boards lack adequate skills in the drafting of budgets, writing financial and policy statements, control of finance and petty cash, initiative and innovation as well as accountability. This was attributed to illiteracy and lack of training among the board members. The current study, therefore, assists in investigating if there is a replica of the same phenomenon founded by Nombasa in Kenyan schools. This will ensure the adoption of a better school financial management in order to realize improved academic performance.

Madikela (2014) argued that school management bodies in South Africa experienced many challenges. These included problems in drafting school budgets, writing financial statement, financial policy, as well as control of finance. Madikela recommended training of the BOM members as the best remedy for such problems. Newly elected BOM members may further experience difficulties in running the school. According to Magiri (2015), newly elected BOM members' competency may be affected by inadequate induction on their responsibilities and roles, low education, inadequate exposure, and inexperience. This has a final effect on the general academic performance of the school.

An examination directed by Tichaona (2015) on the difficulties looked by school heads in the administration 
of school funds in Nkayi District auxiliary schools in Zimbabwe utilized an engaging overview structure. The examination utilized a populace involving 30 auxiliary schools in the District. Irregular inspecting was utilized to concoct an example of ten schools from where 40 participants were intentionally chosen. The examination discovered that most heads of schools came up short on the satisfactory bookkeeping proficiency required for compelling administration of school funds and that there was practically no supervision at all from the Ministry of Primary and Secondary Education money office workforce on budgetary administration and other related issues. This sample size was not adequate to give a good representation on the ground. Thus, the current study was carried out in Kenya, and used a large sample size to give a better representative of the situation. As well, the current study used a mixed research method to enable the researcher to use both qualitative and quantitative approaches in data collection and analysis unlike the previous study that only used a questionnaire method.

Said (2016) conducted a study on the relationship between BOM Management of finances and students' academic achievement in relation to KCSE performance in Mombasa County. The study employed a descriptive survey research design. The study used a sample of 130 participants, including 26 principals and 104 BOM members. Probability sampling procedure was used in sample subjects' selection. The data collection instruments included questionnaires and an interview guide. The study findings show that $40 \%$ of the participants described the BOMs participation in the budget process as satisfactory, while $30 \%$ described it as good. The findings, therefore, mean that the BOM participated in the preparation of the budgets to a large extent. The study recommended that BOMs should be given financial management training to enhance their skills in financial management. Thus, the current study sought to investigate how planning of the budgets in schools would affect financial management and its influence on academic performance among students in public secondary schools in Nyamira County Kenya.

\section{Methodology}

This study adopted a mixed research method approach. Specifically, a convergent parallel mixed method design was used to conduct the study. In this study, the targeted population comprised of the Board of Management (BOM) members, teachers, and students in public secondary schools in Nyamira County. These included 1,728 BOM members; 5,909 teachers; 192 departmental heads, 5 Quality Assurance and Standards Officers and 11,780 form four students (Nyamira County Education Office, 2018). These made up a total target population of 19,276. The study used a sample size computation formula by Krejcie and Morgan (1970) to arrive at the sample of the participants that were used in the study, as follows:

$$
n=\frac{X^{2} * N * P(1-P)}{d^{2}(N-1)+X^{2} * P(1-P)}
$$

Where: $\mathrm{n}=$ the required sample size;

$X^{2}=$ the table value of Chi-square for 1 degree of freedom at the desired confidence level (3.841);

$N=$ the population size;

$P=$ the population proportion (assumed to be 0.50 since this would provide the maximum sample size).

$d=$ the degree of accuracy expressed as a proportion $(0.05)$.

Therefore, the population applicable in the formula included 1,728 BOM members, 5,909 teachers, 11,780 form four students making 19,417 and,

$$
\begin{aligned}
& \mathrm{n}=\frac{3.841 \times 19417 \times 0.5(1-0.5)}{0.05^{2}(19417)+3.841 \times 0.5(1-0.5)}=\frac{18645.17425}{48.5425 \quad .96025} \\
& \quad=376.6 \\
& \quad \approx 377
\end{aligned}
$$

In this study, a sample size of 377 participants was the determined overall proportion of the target population. In order to determine the number of students, teachers, and BOM members from the target population and whose sample size estimate was 377 , the study used a population proportion that is demonstrated as follows. The students sampled were $(11,780 / 19,276 * 377=230)$, teachers were $(5,909 / 19,276 * 377=115)$, BOM members $(23)$ and departmental heads (23) and 5 Quality Assurance and Standards Officers from the five Sub Counties in Nyamira County. Thus, the study used a total sample of 6subjects.

In this study, Questionnaires were used to collect data from the students, teachers and the Board of management members. Interview guides were used to collect information from Heads of academic departments and Quality Assurance and Standards Officers. Observation tool and document analysis were also used by the researcher to collect data on school performance. The study also used inferential statistics and analysis of variance (ANOVA) to find the differences within and between the researched groups and to test the study hypothesis. 


\section{Results}

\subsection{Demographic Information of the Respondents}

In terms of gender; $54.6 \%$ of the students that participated in the study were female, while the remaining $45.4 \%$ of them were male. $82.6 \%$ of the students who took part in the study came from Sub-county schools. This was followed by $13 \%$ who belonged to county schools, while the remaining percentages of $4.4 \%$ were students from national schools.

$67.3 \%$ of the teachers that took part in the study were male, while the remaining $32.7 \%$ of them were female. Teachers whose age was between $20-30$ years accounted for $40.6 \%$, another $25.0 \%$ of them were between $31-40$ years, while $28.1 \%$ of them were between $41-50$ years. Only $6.3 \%$ of the teachers were above 50 years.

In terms of academic qualification, $81.6 \%$ of the teachers had an undergraduate University Degree while $8.2 \%$ of them had a Diploma Certificate. The remaining 10.2\% of the teachers had a Postgraduate academic qualification, which could be either a Postgraduate Diploma or a Master's Degree or a Doctorate Degree.

The BoM members on the same academic qualification issue, indicated their academic qualifications as follows, $66.7 \%$ of them stated that they had an Undergraduate education qualification as the highest academic qualification while $33.3 \%$ of them indicated that they had a Postgraduate academic qualification

\subsection{Influence of the Board of Management Financial Practices on Students' Academic Performance}

The study sought to establish the influence of board of management financial practices on student academic performance.

\subsubsection{Students' level of agreement with some practices of the BOM 's financial management}

Students were required to indicate their agreement on a list of statements from $1=(S A)$-Strongly agree, $2=(A)$ Agree, $3=(U D)$-Undecided, $4=(D)$ - disagree, $5=(S D)$-Strongly disagree $)$. The findings were summarized in Table below.

Table 1

Students' level of agreement with some practices of the BOM 's financial management

\begin{tabular}{|c|c|c|c|c|c|c|c|c|c|c|}
\hline \multirow[t]{2}{*}{ Statements } & \multicolumn{2}{|c|}{$\mathbf{S A}$} & \multicolumn{2}{|l|}{$\mathbf{A}$} & \multicolumn{2}{|c|}{ UD } & \multicolumn{2}{|l|}{ D } & \multicolumn{2}{|l|}{ SD } \\
\hline & $\mathbf{F}$ & $(\%)$ & $\mathbf{F}$ & $\%$ & $\mathbf{F}$ & $\%$ & $\mathbf{F}$ & $(\%)$ & $\mathbf{F}$ & $\%$ \\
\hline $\begin{array}{l}\text { Parents and teachers are involved in planning the } \\
\text { school budget for every school project by the } \\
\text { BOM; }\end{array}$ & 45 & 21.4 & 29 & 13.8 & 9 & 4.3 & 56 & 26.7 & 71 & 33.8 \\
\hline $\begin{array}{l}\text { The way our school uses school money is open } \\
\text { and transparent; }\end{array}$ & 31 & 14.8 & 52 & 24.9 & 17 & 8.1 & 52 & 24.9 & 57 & 27.3 \\
\hline $\begin{array}{l}\text { Records and Reports on the use of school can be } \\
\text { accessed any time you want to see them; }\end{array}$ & 45 & 21.4 & 29 & 13.8 & 9 & 4.3 & 56 & 26.7 & 71 & 33.8 \\
\hline $\begin{array}{l}\text { The funds provided for school development are } \\
\text { well utilized for the benefit of good school } \\
\text { performance; }\end{array}$ & 37 & 18.1 & 48 & 23.5 & 20 & 9.8 & 54 & 26.5 & 45 & 22.1 \\
\hline $\begin{array}{l}\text { The money obtained from school fundraising } \\
\text { activities is well utilized and accounted; }\end{array}$ & 23 & 11.2 & 25 & 12.2 & 24 & 11.7 & 71 & 34.6 & 62 & 30.2 \\
\hline $\begin{array}{l}\text { Previously there has been a case of funds } \\
\text { mismanagement in our school that derailed } \\
\text { learning activities; }\end{array}$ & 46 & 23.0 & 104 & 52.0 & 18 & 9.0 & 16 & 8.0 & 16 & 8.0 \\
\hline $\begin{array}{l}\text { The parents do not pay extra money apart from } \\
\text { school fees; }\end{array}$ & 94 & 47.0 & 53 & 26.5 & 4 & 2.0 & 27 & 13.5 & 22 & 11.0 \\
\hline
\end{tabular}

Key: SA: Strongly Agree; A: Agree; UD: Undecided; D: Disagree, SD Strongly Disagree; $n=216$

From Table 1, it is clear that, $63.4 \%$ of the students disagreed with the statement that BoM involved parents and teachers in planning the school budget for school projects, while $35.2 \%$ of them agreed. Only $4.3 \%$ were undecided.

When asked to indicate if the funds provided for school development are well utilized for the benefit of good school performance; almost half $(48.6 \%)$ of the students disagreed. On the other hand $41.6 \%$ agreed that funds were well utilized.

Almost two-thirds $(64.8 \%)$ of the student respondents disagreed with the statement that money obtained from 
school fundraising activities is well utilized and accounted for. Only $23.4 \%$ of the respondents agreed with the statement.

An overwhelming majority ( $75 \%)$ indicated that there were no cases where mismanagement of funds derailed learning activities within the school. Only $16 \%$ of respondents were of the contrary opinion.

\subsubsection{Teachers' and BoM's Views on Financial Management Practices of BOM}

Teachers and board of management members were required to append their agreement on a list of statements from $1=(S A)$ - Strongly agree, $2=(A)$ - agree, $3=(U D)$-Undecided, $4=(D)$ - disagree, $5=(S D)$ - Strongly disagree $)$ The findings were summarized in Table below.

Table 2

Financial Management Practices of BOM

\begin{tabular}{|c|c|c|c|c|c|c|c|c|c|c|c|}
\hline \multirow[t]{2}{*}{ Statement } & \multirow[t]{2}{*}{ Category } & \multicolumn{2}{|l|}{$\mathbf{S A}$} & \multicolumn{2}{|l|}{$\mathbf{A}$} & \multicolumn{2}{|c|}{ UD } & \multicolumn{2}{|l|}{$\bar{D}$} & \multicolumn{2}{|c|}{ SD } \\
\hline & & $\mathbf{F}$ & $\%$ & $\mathbf{F}$ & $\%$ & $\mathbf{F}$ & $\%$ & $\mathbf{F}$ & $\%$ & $\mathbf{F}$ & $\%$ \\
\hline \multirow{2}{*}{$\begin{array}{l}\text { Parents and teachers are involved } \\
\text { in planning the school budget for } \\
\text { every school project by the BOM; }\end{array}$} & Teachers & 7 & 7.7 & 17 & 19.2 & 15 & 17.3 & 22 & 25.0 & 26 & 30.8 \\
\hline & BoM & 3 & 14.3 & 11 & 52.4 & 2 & 9.5 & 5 & 23.8 & - & - \\
\hline \multirow{2}{*}{$\begin{array}{l}\text { The way our school uses school } \\
\text { money is open and transparent; }\end{array}$} & Teachers & 3 & 3.9 & 12 & 13.7 & 14 & 15.7 & 29 & 33.3 & 29 & 33.3 \\
\hline & BoM & 6 & 28.6 & 7 & 33.3 & - & - & 5 & 23.8 & 3 & 14.3 \\
\hline \multirow{2}{*}{$\begin{array}{l}\text { Financial records and reports on the } \\
\text { use of school can be accessed any } \\
\text { time you want to see them; }\end{array}$} & Teachers & 9 & 10.4 & 9 & 10.4 & 16 & 18.8 & 38 & 43.7 & 14 & 16.7 \\
\hline & BoM & 9 & 42.9 & 5 & 23.8 & 1 & 4.8 & 4 & 19 & 2 & 9.5 \\
\hline \multirow{2}{*}{$\begin{array}{l}\text { The funds provided for school } \\
\text { development are well utilized for the } \\
\text { benefit of good school performance; }\end{array}$} & Teachers & 3 & 4.0 & 15 & 18.0 & 17 & 20.0 & 19 & 22.0 & 31 & 36.0 \\
\hline & BoM & 6 & 28.6 & 7 & 38.1 & 1 & 4.8 & 3 & 14.2 & 2 & 9.5 \\
\hline \multirow{2}{*}{$\begin{array}{l}\text { The money obtained from school } \\
\text { fundraising activities is well utilized } \\
\text { and accounted; }\end{array}$} & Teachers & 5 & 5.9 & 22 & 25.5 & 12 & 13.7 & 17 & 19.6 & 30 & 35.3 \\
\hline & BoM & 10 & 47.6 & 4 & 19 & 1 & 4.8 & 4 & 19 & 2 & 9.5 \\
\hline \multirow{2}{*}{$\begin{array}{l}\text { Previously there has been a case of } \\
\text { funds mismanagement in our school } \\
\text { that derailed learning activities; }\end{array}$} & Teachers & 10 & 11.5 & 7 & 7.7 & 13 & 15.4 & 13 & 15.4 & 35 & 40.4 \\
\hline & BoM & 6 & 28.6 & 4 & 19 & - & - & 7 & 33.3 & 3 & 14.3 \\
\hline \multirow{2}{*}{$\begin{array}{l}\text { The parents do not pay extra money } \\
\text { apart from school fees; }\end{array}$} & Teachers & 32 & 36.7 & 32 & 36.7 & 5 & 5.9 & 14 & 16.3 & 4 & 4.1 \\
\hline & BoM & 8 & 38.1 & 7 & 33.3 & 1 & 4.8 & 4 & 19.0 & 1 & 4.8 \\
\hline
\end{tabular}

Key: SA - Strongly Agree; A - Agree; UD - Undecided; D - Disagree, SD - Strongly Disagree; $n$ (Teachers) $=87 ;$ $n(B o M s)=21$

As shown in Table, the study participants were asked to indicate whether parents and teachers are involved in planning the school budget for every school project by the BOM. Slightly more than half $(55.8 \%)$ of the teachers disagreed. On the other hand, two third $(66.7 \%)$ of board of management participants strongly agreed that everyone, including parents, teachers, non-teaching staff, and the students are involved in planning the school budget for every school project by the BOM.

With regards to access to financial records and reports of how schools use their finances, almost two-thirds $(60.4 \%)$ of teachers indicated that they could not be accessed at any time. This starkly contrasts the two-third $(66.7 \%)$ of the board of management that agreed that school financial records were accessible.

On whether there was a case of fund mismanagement that derailed learning activities, slightly more than half $(55.8 \%)$ of the teachers disagreed. Slightly less than half $(47.6 \%)$ of the board of management members disagreed with the statement.

In an interview on whether the funds provided for school development were well utilized for the benefit of good school performance; One HOD stated that:

...the reason why public secondary schools perform poorly in Nyamira is because of misappropriation of school funds that limit the availability of funds for procurement of teaching and learning facilities. This include facilities like good classrooms, equipped laboratories, library with adequate current revision materials, and computer laboratory with stable connection to internet for use by students and teachers for accessing current knowledge on their subject areas (Ssch14 HoD, May 16, 2019). 
4.3 Relationship between BOM`s Financial Management Practice and the Students' Academic Performance $\mathrm{H}_{\mathrm{O} 1}$ : There is no statistical significant association between BOM's financial management practice and students' academic performance in public secondary schools in Nyamira County;

Analysis of variance was performed so as to establish whether there is a statistically significant association between BOM's financial management practice and the students' academic performance in public secondary schools in Nyamira County. Table below shows the analysis of variance.

Table 3

Regression Model Significance of BOM `s Financial Management Practice

\begin{tabular}{|c|c|c|c|c|c|c|}
\hline \multicolumn{2}{|c|}{ Model } & Sum of Squares & Df & Mean Square & $\mathrm{F}$ & Sig. \\
\hline 1 & Regression & 6.231 & 8 & .779 & 2.582 & $.010^{\mathrm{b}}$ \\
\hline & Residual & 76.636 & 208 & .302 & & \\
\hline & Total & 82.967 & 216 & & & \\
\hline
\end{tabular}

The $F$-ratio in the ANOVA table tests whether the overall regression model is a good fit for the data and whether the model, overall, results in a significantly good degree of prediction of the dependent variable. Table 3 shows that the joint independent variables statistically significantly predict the dependent variable, $F(8,208)=$ 2.582, $p=.010$, and that other variables not included in this model may have accounted for the remaining variance. Thus, the regression model was a good fit for the data. Since the overall F-test is significant, it is concluded that R-squared does not equal zero, and the correlation between the model and dependent variable is statistically significant. The study therefore rejects the null hypothesis.

\section{Discussion}

This study sought to establish whether school money was utilized in an open and transparent manner. Slightly more than half (52.2\%) of students disagreed that school money was used in transparent manner. This could be attributed to the fact that the board of management does not update the school community about the progress of school projects. These findings imply that most schools' board of management in the County do not involve parents and teachers in planning the school budget for every school project, although the parents and teachers have a representative in the board of management through PTA. This concurs with Otieno (2011) who found that the schools board of management does not consult teachers and parents in matters pertaining ongoing school activities, there is a poor attitude by the parents, a minimum attendance of fundraising, low income from the community and lack of accountability and that non-involvement make parents uncooperative to support school projects. They could have informed parents and other stakeholders on the use of school funds through school newsletters and magazines.

The study further sought information as to whether the money obtained from school fundraising activities is well utilized and accounted for. Nearly two thirds (64.8\%) of the student respondents disagreed. This is indicative that most BOM does not utilize the funds from fundraising activities for the projects that it was meant to finance. This may affect the teaching and learning activities in the affected schools, which consequently contribute to the dismal academic performance of schools in Nyamira County. The findings concur Tichaona (2014) who found that most heads of schools in Zimbabwe lacked adequate involvement in the accounting of school funds which is required for effective management of school finances, and that there was little or no supervision at all from the Ministry of Primary and Secondary Education finance department personnel on financial management and other related issues.

On whether there has been a case of funds mismanagement in their school that derailed learning activities previously, $52.0 \%$ of the student participants strongly agreed with the statement. This implies there have been cases of funds mismanagement in their school that derailed learning activities among schools in the region. Slightly less than half $(43.2 \%)$ of the teachers indicated that money was poorly utilized. Only $15.9 \%$ of the teachers were positive that money was well utilized. This shows that most school administrators did not utilize school funds well. This finding concurred by Mobegi et al., (2012) who established that the level of financial mismanagement in secondary school was high. Mobegi et al., revealed that the major forms of financial mismanagement in schools included exaggerated travelling allowances, unauthorized purchases of personal gains, Board of governors visiting schools frequently and given allowances, exaggerated prices of repairs, contracts awarded to a related party, exaggerated prices of school items especially for stationeries and boarding, and exaggerated expenditure on cocurricular activities.

Most of the students noted that BoM does not use school funds well. This was also supported by most of the teachers who agreed that the BoM did not utilize school funds efficiently for the benefit of the school. The study further established that funds provided for school development were not well utilized for the benefit of good school performance in most schools in Nyamira County. These study findings concur with Ntsele, (2014) who established inefficiencies in the financial management of most public Primary schools in Johannesburg South Africa contribute 
to the decline in quality of education. The study findings therefore reveal gaps in effective management of school funds by the Boards of management in public secondary schools in Nyamira County.

\section{Conclusion}

The study established that board of management finance practice is the key determinant of the students' academic performance in public secondary schools in Nyamira County. The study findings indicated a statistical significant association between BOM financial practices and student academic performance $F(8,208)=2.582, p=.010)$. The study recommends that school board of management should lobby for more funding from governmental and non-governmental agencies in order to support the school developments. The utilization of the funds by the board of management should also portray a high level of expertise, integrity, and accountability for efficient utilization of the school funds. The board of management should also prioritize reasonable projects that would attribute to the maximum improvement of school performance. Also, the board of management, in collaboration with the government, should ensure appointment of board members with some basic financial management literacy.

\section{References}

Kalungu, A. S. (2015). Influence of board of managements' financial management on public secondary schools in Westlands district, Nairobi County, Kenya (Doctoral dissertation, University of Nairobi).

King'oina, J. O., Ngaruiya, B. N., \& Mobegi, F. O. (2017). The Role of Boards of Management as a Determinant of Pupils' Academic Performance in Public Primary Schools in Marani Sub-County, Kenya. International Journal of Scientific Research and Innovative Technology 4 (6)

Krejcie, R., \& Morgan, D. (1970). Determining sample size for study activities. Retrieved fromhttps://home.kku.ac.th/sompong/guest_speaker/KrejcieandMorgan_article.pdf, on September 2018.

Kwesi A.E., Arko, A. \& Maison, R. (2018). Assessment of School Governance Practices in Senior High Schools in Ghana. 6. 237-247.

Langat, G. (2008). An evaluation of the impact of government instructions on financial management in public secondary schools in Kenya. Nairobi: University Press.

Madikela, T. (2006). Problems experienced by school Governing Bodies in the Execution of their Financial Management task. Unpublished Med Project, University of South Africa.

Max Roser and Esteban Ortiz-Ospina (2016) - "Financing Education". Published online at OurWorldInData.org. Retrieved from: 'https://ourworldindata.org/financing-education'

Ministry of Education, Science and Technology. (2014) national education sector plan .Retrieved from:https://planipolis.iiep.unesco.org/sites/planipolis/files/ressources/kenya_nesp_vol_1.pdf

Mobegi, F., Ondigi, B., \& Simatwa, E. (2012). Factors contributing to financial mismanagement and misappropriation in Public Secondary Schools in Gucha District, Kenya. International Journal of Exclusive Management Research, 2(5): 1-19.

Molano-León, R. (2011). The roles of the board of directors: the unresolved riddle. Vniversitas, (122), 541-602.

Ntsele, C. N. (2014). Accountability and Transparency in Managing School Finances at Primary Schools in Johannesbug South Africa (Doctoral dissertation, University of South Africa).

Nyakundi, N., Okiaga, C., Ojera, P., Nyabwanga, N. \& Nyamwamu, T. (2008). An assessment of the effect of accounting practices on the management of funds in public secondary schools: A study of Kisii Central District, Kenya.

Otieno, H. O. (2011). Challenges faced by board of governors in the management of public secondary schools in Uriri District, Kenya (Doctoral dissertation, University of Nairobi, Kenya).

Lewis, M. \& Pettersson, G. G. (2009). Governance in Education: Raising Performance. SSRN Electronic Journal. $10.2139 /$ ssrn. 1992404.

Said, K. (2016). Influence of board of managements' resource management on students' academic achievement in Public secondary schools, Mombasa County, Kenya. (Unpublished Master's thesis, University of Nairobi, Nairobi, Kenya).

Shkurina, E. (2018). Financial management functions of the school principal. Retrieved from:https://blog.youragora.com/financial-responsibilities-of-school-principals-explained

Tichaona, M. (2014). Challenges faced by school heads in the management of school finances in Nkayi district secondary schools. Harare: Zimbabwe Open University.

Transparency international (october 2011 - september 2012). Annual report. Retrieved from: https://tikenya.org/wp-content/uploads/2017/06/ti-kenya-annual-report-2011-2012-1.pdf

World Bank, (2014). Final Report on study of management of education in Kenya. New York: World Bank. 